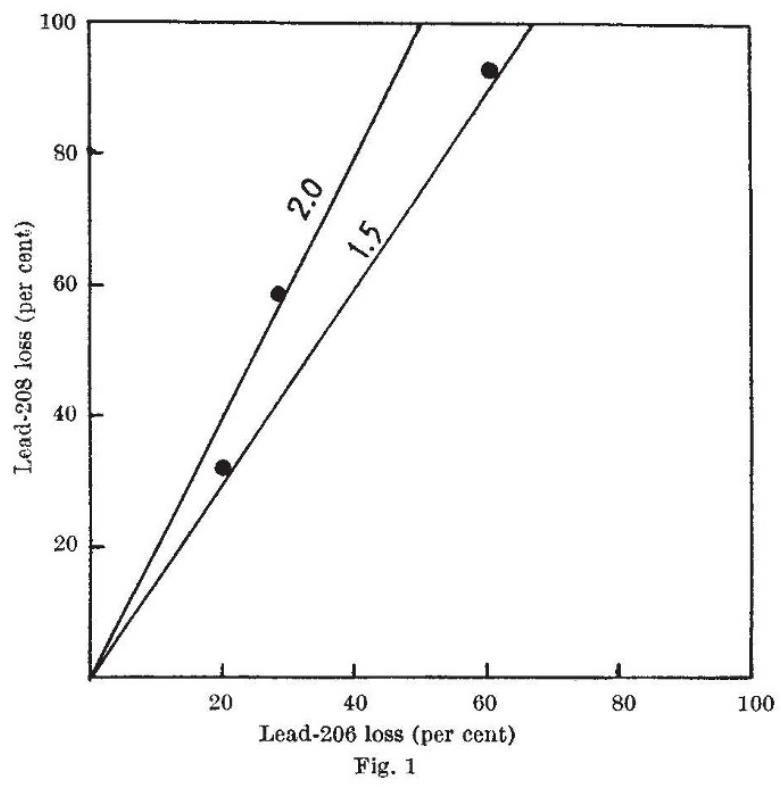

as follows: for example, 1.94 was derived from $\left(73 \cdot 0_{-}\right.$ $26 \cdot 2) /(50 \cdot 3-26 \cdot 2)$.

Also the existence of other elements in the radiationaffected zone may have bearing on the problem under consideration. However, attention might be attracted to the fact that the ratios of lost percentage of lead-208 to lead-206 in specimens participating in Rhodesia pattern scrutinized by Ahrens ${ }^{4,5}$ are about 1.5 and 2.0 (Fig. 1).

Institute for Nuclear Study, Akimasa Masuda

University of Tokyo, Tanashi, Tokyo.

' Wetherill, G. W., Geochim. et Cosmochim. Acta, 9, 290 (1956).

2 Tilton, G. R., Trans. Amer. Geophys. Union, 37, 224 (1956).

${ }^{3}$ Kulp, J. L., and Eckelmann, W. R., Amer. Mineralogist, 42, 154 (1957).

4 Ahrens, L. H., Geochim. et Cosmochim. Acta, 7, 294 (1955).

s A hrens, L. H., Geochim. et Cosmochim. Acta, 8, 1 (1955).

\section{Age Determination of some Yugoslav Granites and Granodiorites by the Rubidium/Strontium Method}

THE age of four samples of granitic rocks selected by the Establishment for Nuclear Materials (Beograd, Yugoslavia) has been measured by the rubidium/strontium method. All analyses were made on biotite fractions; the usual techniques of isotopic dilution were used for the determinations of rubidium and strontium, utilizing an Atlas CH4 mass-spectrometer equipped with a normal collector.

The following results have been obtained:

39025-Stara Planina. Granitic rock, coarso grained, with ipidiomorphic structure with a reddish coloration due to abundant large potassium feldspar crystals. The biotite frequently appears with idiomorphic crystals and seems rather fresh.

38772-Biotite from a granitic rock of the same locality. Stara Planina granite is considered to be one of the oldest Yugoslav intrusive rocks, and it seems very probable that this granite was formed during the Hercynian orogeny.

49438-Dunye (Pelagonia-Macedonia). Biotite from a rock intermediate between granite and granodiorito.

The sample comes from a geologically not well-known locality in which the rocks are characterized by a heavy metasomatic action and seem to form a para-series including gneiss, granitic gneisses, migmatitos, etc. A pegmatite sample was analysed in a Russian laboratory. The age obtained on the muscovite by the potassium/argon method is 140 million years.

\begin{tabular}{|c|c|c|c|c|c|}
\hline $\begin{array}{c}\text { Sample } \\
\text { No. }\end{array}$ & $\begin{array}{c}\text { Total Rb } \\
\text { (p.p.m.) }\end{array}$ & $\begin{array}{l}\text { Total Sr } \\
\text { (p.p.m.) }\end{array}$ & $\begin{array}{c}\text { Radiogenic }{ }^{87} \mathrm{Sr} \\
\text { (p.p.m.) }\end{array}$ & $\frac{\text { Radiogenic }{ }^{87} \mathrm{Sr}}{\text { Total }}$ & $r \begin{array}{c}\text { Age } \\
\text { (m.y.) }\end{array}$ \\
\hline $\begin{array}{l}39025 \\
38772 \\
59052 \\
49438\end{array}$ & $\begin{array}{l}516 \pm 9 \\
642 \pm 11 \\
413 \pm 7 \\
708 \pm 13\end{array}$ & $\begin{array}{l}9.17 \pm 0.13 \\
5.65 \pm 0.08 \\
8.40 \pm 0.12 \\
2.66 \pm 0.04\end{array}$ & $\begin{array}{l}0.6474 \pm 0.0160 \\
0 \cdot 7565 \pm 0 \cdot 0190 \\
0 \cdot 0642 \pm 0 \cdot 0077 \\
0.3875 \pm 0.0096\end{array}$ & $\begin{array}{l}0 \cdot 50 \\
0 \cdot 65 \\
0 \cdot 10 \\
0 \cdot 67\end{array}$ & $\begin{array}{l}300 \pm 11 \\
282 \pm 10 \\
37 \cdot 3 \pm 5 \\
131 \pm 5\end{array}$ \\
\hline
\end{tabular}

59052-Iastreboc (Central Serbia). Biotite from a granodiorite with ipidiomorphic structure without any mechan. ical deformation. Biotite crystals, sometimes lightly chloritized, are very large.

The granodiorite intruded a Palæozoic series causing a strong contact metamorphism.

The results obtained for the samples 39025 and 38772 confirm the Hercynian age postulated for the Staria Planina granite.

The age of 131 m.y. for the sample 49438 agrees with that determined by the potassium/argon method, and is probably related to an ultrametamorphic phase concluded at the end of the Jurassic period.

The sample 59052 gives an Alpine age which agrees with geological information.

Zavod za Nucklearne Sirovine,

\section{Z. Cervenjak} Belgrade, Yugoslavia.

\section{G. Ferrara}

E. TONGIORGI

Laboratorio di Geologia Nucleare del CNEN, Pisa, Italy.

\section{GEOLOGY}

\section{The Precambrian Atmosphere}

In his recent book on The Geological Aspects of the Origin of Life on Earth, Prof. M. G. Rutten has adopted as his central thesis the postulate that the Earth retained its primæval reducing atmosphere up to $1,500-2,000$ million years ago. This conclusion is based on the premise that the gold-uranium ores of the Witwatersrand (South Africa), Blind River (Canada), and Serra de Jacobina (Brazil) are fossil alluvial deposits, in which the notionally detrital uraninite and pyrite are supposed to have survived weathering because the deposits reputedly accumulated under anoxygenic conditions. Nowhere in his work does Prof. Rutten mention that scores of papers have been written by geologists of international reputation to show that these ore-bodies ('bankets') have been formed within the Earth's crust long after the mother-rock sediments were laid down, by the infiltration of hydrothermal metalbearing solutions. A lengthy review by Prof. J. D. Bernal ${ }^{1}$ commends this book to Nature's wide circle of readers as "a welcome fresh light on one of the most exciting problems of the day", the reviewer apparently being unaware that the origin of the Witwatersrand gold deposits has remained one of the most controversial issues of economic geology for more than half a century, and that since the discovery of commercial uranium in these ores the arguments have increased in number, vigour and acerbity. Most geologists will know that both sides of the question are recounted at length in the leading American, French and Russian text-books on uranium geology, as well as in the official publications of the South African, Canadian, and United States Geological Surveys. Other roaders, however, should be warned that the validity of Prof. Rutten's conclusions is no groator than that of his fundamental premise, and that this is very debatable indeed.

The arguments against the hypothetical alluvial origin of these ore-bodies are much too numerous to be summarized here, and it will suffice to say that the placerist conceptions can only be sustained by a long series of perversions of chemical and physical laws ${ }^{2}$. It is rolevant that in the Mozaan rocks of Swaziland deposited concurrently with the Witwatersrand strata, and in the Lorrain sandstones 